\title{
Karakterisasi Kayu yang Difungsikan sebagai Pasak Baru pada Pemugaran Perahu Kuna di Situs Punjulharjo, Rembang
}

\author{
Yustinus Suranto \\ Fakultas Kehutanan, Universitas Gadjah Mada \\ Email : suranto@ugm.ac.id
}

\begin{abstract}
Abstrak : Pada tahun 2008, perahu kuna terbuat dari bahan kayu ditemukan di Desa Punjulharjo Kabupaten Rembang. Perahu selesai direkonstruksi pada tahun 2014 dan dilanjutkan dengan programkonservasi sampai dengan tahun 2017. Pada saat pelaksanaan rekonstruksi, seluruh pasak yang berbahan kayu kuno diganti dengan pasak baru berbahan kayu baru. Penggantian dilakukan tanpa didahului dengan studi diagnostik pasak kayu sebagaimana diamanatkan dalam UU Nomor 11 tahun 2010 tentang Cagar Budaya, sehingga upaya mempertahankan orisinalitasjenis tidak diperhatikan. Pemerintah Republik Indonesia akan membangun Museum Maritim Nasional di situs Punjulharjo pada tahun 2017. Karakterisasi kayu yang difungsikan sebagai pasak baru sangat diperlukan sebagai data yang dapat diperankan sebagai sumber informasi bagi kepentingan museum tersebut. Penelitian ini bertujuan untuk mengidentifikasi jenis, sifat-sifat kayu serta kualitas kayu baru yang difungsikan sebagai pasak.

Bahan penelitian ini adalah kayu lebihan dalampembuatan pasak yang disimpan oleh kepala tukang rekonstruksi. Penelitian penentuan jenis kayu dilakukan dengan metode identifikasi makroskopis. Sifat fisika dan mekanika kayu ditentukan denganmetodeBritish Standard 373. Kualitas kayu ditentukanberdasarkan berat jenis dan kekuatan tekan kayu. Klasifikasi kualitas kayu berdasarkan berat jenis dilakukan dengan mengikutimetode Seng (1964), sedangkankekuatan tekan sejajar serat dilakukan dengan mengikuti Anonim (1976).

Hasil penelitian menyimpulkan empat hal. Pertama, jenis kayu adalah pilang (Acacia leucophloea Wild). Kedua, berat jenis kayu kering udara adalah 0,82 . Ketiga, keteguhan tekan sejajar serat $778 \mathrm{~kg} / \mathrm{cm}^{2}$. Keempat, peringkat kelas kualitas adalah kelas I-II, sehingga kayu ini berstatus sebagai kayu yang sangat baik sampai dengan baik.
\end{abstract}

Kata Kunci: identifikasi, karakter, kualitas, pasak kayu, perahu, punjulharjo

Abstract: In 2008, old wooden boat were found in Punjulharjo Village, Rembang Regency. Reconstruction of the boat has been completed in 2014 and is being continued by conservation activities until the end of 2017. At the time of the reconstruction activities, all of heritage wooden pegs were replaced by new wooden ones. The replacement of wooden pegs was carried out without the diagnostic study of these boat element as mandated by Law No. 11 of 2010 on Cultural Heritage, so the effort to maintain the wood species originality was not considered. The Government of the Republic of Indonesia was planning to build the National Maritime Museum at the site of Punjulharjo in 2017. Characterization of wood used as a new peg was very important to do in order to obtain data that can function as a source of information for the future museum. This study aims to identify the species, the properties and the quality of new wood which was used as material for the new pegs.

The research material was a residual wood used by the team for reconstructing the old boat at the time of making boat's pegs. This residual timber was originally kept by the head of the team. Research for determination of wood species was done by using macroscopic identification method, whereas for determination of the wood physical and mechanical properties were done by using British Standard Method number 373 - 1957. The wood quality was determined based on two parameters, namely specific gravity and grain-parallel compressive strength. In term of specific gravity, quality classification developed by Seng (1964) was used, whereas in term of compressive strength, a general type of wood quality classification was used.

The study resulted into four points of conclusion. First, the wood species was Pilang (Acacia leucophloea Wild). Second, air dry wood density was 0.82 . Third, the grain- parallel compressive strength was $778 \mathrm{~kg} / \mathrm{cm} 2$. Fourth, the wood quality class was I - II. This class means that this wood belongs to an excellent or good wood.

Keywords: wood identification, character, quality, pegs, boat, punjulharjo

\section{Pendahuluan}

\subsection{Latar Belakang}

Pada tahun 2008, ditemukan sebuah perahu kuna yang terbuat dari kayu di Desa Punjulharjo Kabupaten Rembang dan diperkirakan berfungsi pada abad ke-7 Masehi. Pada tahun 2014, perahu ini telah selesai direkonstruksi dan ditindaklanjuti dengan aktivitas konservasi. Konservasi dilakukan dengan perendaman dalampoli-etilin-glykoldan akan berakhir pada tahun 2017. Saat melakukan rekonstruksi, seluruh pasak kayu kunodiganti dengan pasak kayu baru yang dipilih berdasarkan teknologi tradisional masyarakat maritim 
Rembang. Penggantian pasak dilakukan tanpa didahului studi diagnostikterhadap kayu tersebut, sehingga mengesampingkanprinsip orisinalitas bahan, bentuk, ukuran, karakter dan cara pengerjaan bahan sebagaimana diamanatkan dalam Undang-Undang Nomor 11 tahun 2010 tentang Cagar Budaya.

Pemerintah Republik Indonesia berencana untuk membangun Museum Maritim Nasional disitus Punjulharjo pada tahun 2017 (Widianto, 2015). Oleh karena itu, informasi tentang jenis dan sifat-sifat kayu yang difungsikan sebagai pasak baru itu sangat diperlukan sebagai bahan edukasi untuk pengunjung museum. Namun, informasi tentang jenis dan sifat-sifat kayu tersebut belum tersedia sampai saat ini. Maka penelitian tentang karakterisasi jenis, sifat-sifatdan kualitas kayu sebagai pasak yang baru bagi perahu kuna sangat perlu untuk dilakukan. Sifat-sifat kayu meliputi antara lain sifat struktur, sifat fisika, dan sifat mekanika kayu.

Jenis kayu dapat ditentukan melalui aktivitas identifikasi kayu dengan melakukan pengamatan terhadap struktur makroskopis kayu dan/atau anatomi kayu. Pengamatan struktur makroskopis kayu bertujuan untuk mengenal komponen-komponen seluler penyusun kayu yang dilakukan dengan cara mengamati struktur dan tekstur kayu. Komponen sel-sel penyusun kayu meliputi serabut, trakeid, pembuluh, jari-jari, parenkim, dan saluran damar. Pengamatan terhadap struktur kayu dilakukan melalui pengamatan terhadap keberadaan, posisi dan konfigurasi komponen sel-sel penyusun kayu. Secara makroskopis, konfigurasi ini membentuk lingkaran pertumbuhan, kayu gubal-kayu teras, kayu awal-kayu akhir. Pengamatan terhadap tekstur kayu dilakukan melaluipengamatan secara makro tentang dimensi ukuran komponen sel-sel penyusun kayu, sehingga dikenal kayu bertekstur halus, sedang dan kasar (Soenardi, 1977).

Sifat-sifat fisika kayu mencakup antara lain kadar air kayu, berat jenis kayu, penyusutan kayu. Kadar air kayu menyatakan banyaknya air yang dapat dikandung di dalam kayu. Berat jenis kayumerupakan perbandingan antara berat kayu dalam kondisi kering mutlak dan volume kayu tersebut. Penyusutan dimensi kayu terjadi ketika kayu tersebut mengering dari kondisi titik jenuh seratnya, atau sebaliknya, besarnya pengembangan dimensi kayu ketika kayu menjadi lebih basah dari kondisi di bawah kondisi titik jenuh serat. (Kollman dan Cote, 1968, Forest Product Laboratory, 1999).

Besarnya perubahan dimensi kayu tidak sama pada ketiga arah sumbu kayu, yaitu arah tangensial, radial, dan longitudinal. Pada kayu normal, besarnya nilai penyusutan arah tangensial 4,3-14\%, arah radial $2,1-8,5 \%$ dan arah longitudinal $0,1-0,2 \%$. Perbandingan antara pengerutan tangensial dan radial dapat digunakan sebagai indikator untuk menaksir tingkat kestabilan kayu dalam arah sumbu sel. Bila perbandingan itu semakin mendekati angka 1, maka kayu itu dinyatakan semakin stabil (Soenardi, 1976; Shmulsky dan Jones, 2011).

Sifat mekanika kayu merupakan suatu aspek yang berkaitan dengan karakter kekuatan kayu, yaknikemampuan kayu untuk menahan muatan yang dibebankan kepadanya. Karakter ini dapat dirinci menjadi beberapa parameter. Penentuan jenis parameter yang paling tepat untuk ditampilkan, bergantung pada dua hal, yaitu (1) jenis dan arah gaya membebani kayu, dan (2) wujud pengorganisasian pada kayu saat menerima beban (Prawirohatmodjo, 2001). Kekuatan kayu meliputi kekuatan lengkung statik, kekuatan tekan, kekuatan tarik, kekuatan geser dan kekuatan belah serta kekerasan kayu (Kollman dan Cote, 1968).

Sifat fisika dan sifat mekanika kayu dapat ditentukan dengan berbagai metode pengujian. Salah satu diantaranya adalah metode pengujian berdasarkan British Standard nomor 373 tahun 1957. Metode pengujian ini sesuai untuk pengujian kayu dengan dimensi kecil, yakni contoh uji dengan penampang berbentuk bujur sangkar dengan sisi berukuran $2 \mathrm{~cm}$. Contoh-uji tersebut dipersyaratkan untuk bebas dari cacat-cacat kayu dan kadar air $14 \%$.

Berdasarkan sifat fisika terutama dalam parameter berat jenis dan sifat mekanika terutama dalam parameter kekuatan tekan, kayu dikelompokkan ke dalam lima kelompok kelas kayu(Anonim, 1976). Oleh karena itu, berat jenis dan kekuatan tekan kayu menjadi salah satu dasar untuk menentukan kualitas kayu.

Kualitas kayu merupakan suatu konsep mengenai kondisi baik-tidaknya suatu kayu yang diorientasikan pada kegunaan tertentu kayu. Konsep kualitas kayu berkembang sesuai dengan perkembangan ilmu-ilmu kehutanan, khususnya yang mencakup ilmu silvikultur, ilmu kayu serta teknologi kayu. Dalam konteks ilmu 
dan teknologi kayu, sifat fisika dan sifat mekanika kayu digunakan sebagai dasar untuk menentukan kualitas kayu, khususnya parameter berat jenis dan kuat tekan kayu. Dalam konteks kedua parameter ini, Seng (1964) membuat klasifikasi kualitas kayu menjadi lima kelas berdasarkan nilai berat jenisnya. Kelas kualitas I, II, III, IV dan $\mathrm{V}$ adalah kelas kualitas yang secara berurutan ditandai dengan berat jenis $>0,90 ; 0,6-0,9 ; 0,4-0,59$; $0,3-0,39$ dan $<0,3$.Sementara itu, ada klasifikasi lain yang juga membagi kelas kualitas kayu menjadi lima kelas berdasarkan nilai kuat tekan sejajar kayu. Kelas kualitas I, II, III, IV dan V adalah kelas kualitas yang secara berurutan ditandai dengan kekuatan tekan kayu sebesar $>$ 650, 425 - 650, 300 - 424, 215 - 299 dan $<215$ (Anonim, 1976).Kelas kualitas I lebih baik daripada kelas kualitas II dan seterusnya.

\subsection{Metodologi Penelitian}

a. Bahan Penelitian

Bahan penelitian berupa sepotong kayu lebihan bagian dari kayu pasak baru yang digunakan pada rekonstruksi perahu kuna Situs Punjulharjo. Setelah proses pemugaran dinyatakan selesai, kayu lebihan ini disimpan oleh seorang tukang yang menjabat sebagai ketua tim tukang yang dulu bertugas dalam pemugaran perahu kuna. Keberadaan kayu lebihan ini telah diketahui oleh tim peneliti Balai Konservasi Borobudur sejak mendapatkan tugas untuk mengawal proses pemugaran perahu tersebut.Atas permohonan penulis, kelompok kerja yang beranggotakan diantaranya Nahar Cahyandaru, S.Si., M.A,dan Aris Munandar ini melakukan pelacakan kembali terhadap keberadaan kayu lebihan tersebut, untuk selanjutnya diserahkan kepada penulis sebagai obyek penelitian.

b. Prosedur Penelitian

Penelitian bertujuan untuk mengkarakterisasikan kayu sebagai pasak baru perahu kuna di situs Punjungharjodengan limatahapan kegiatan sebagai berikut:

1. Penelitian dimensi fisik kayu lebihan sebagai bahan pembuatan pasak.

2. Penelitian jenis kayu dilakukan dengan metode identifikasi kayu berdasarkan karakter struktur dan sifat makroskopis kayu. Contoh uji kayu diiris dengan menggunakan mikrotom model 860 buatan American Optical Corporation USA untuk mendapatkan penampang transversal. Penampang transversal dipotret secara makroskopis pada pembesaran 15 kali dengan menggunakan mikroskop Olympus BX-51. Gambar yang dihasilkannya diamati komponen struktur makroskopis.

3. Penelitian sifat fisika kayu dilakukan berdasarkan metode British Standard nomor 373 tahun 1957.

4. Penelitian sifat mekanika kayu dilakukan berdasarkan metode British Standart nomor 373 tahun 1957.

5. Penentuan kualitas kayu dilakukan berdasarkan nilai berat jenis dan kekuatantekan.

\section{Hasil Penelitian dan Pembahasan}

Hasil penelitian dikelompokkan menjadi empat bagian, yaitu (1) data dimensi fisik kayu lebihan sebagai bahan pembuatan pasak, (2) data jenis kayu, (3) data sifat fisika kayu, (4) data sifat mekanika kayu, (5) perumusan kualitas kayu. Masing-masing data tersebut dijelaskan pada uraian di bawah ini.

\subsection{Dimensi Kayu Lebihan Pada Pembuatan Pasak}

Kayu lebihan sebagai pasak baru berupa potongan pada bagian pangkal batang. Dari hasil pengukuran, diperoleh dimensi kayu obyek penelitian dengan diameter pangkal rata-rata $14,5 \mathrm{~cm}$, diameter ujung rata-rata 12,5 $\mathrm{cm}$ dan panjang $28 \mathrm{~cm}$. Secara keseluruhan, postur kayu obyek penelitian ini disajikan pada beberapa di bawah.

\subsection{Identifikasi Jenis Kayu}

Untuk mengidentifikasi kayu, diambil contoh uji dan diiris dengan ketebalan 20 mikro meter, kemudian difoto secara makroskopis terhadap penampang melintangnya. Hasilnya disajikan pada Gambar 6 dan 7 di bawah.

Pengamatan foto makroskopis dilakukan terhadap ciri-ciri struktur sitologis elemen penyusun kayu. Hasil pengamatan dapat dideskripsikan sebagai berikut: 
a. Lingkaran tahun tampak jelas. Ada dua penyebab kenampakan lingkaran tahun ini, yaitu, (1) perbedaan warna antara kayu awal dan kayu akhir yang terlihat pada Gambar 7, dan (2) perubahan dimensi pembuluh pada kayu awal dan kayu akhir yang terlihat pada Gambar 6 .

b. Pembuluh memiliki persebaran tunggal dan ganda radial.

c. Parenkim bertipe paratrakheal (parenkim yang bersinggungan dengan pembuluh). Parenkim paratrakheal berjenis parenkim vasisentrik, yaitu parenkim yang menyelubungi secara penuh atau lengkap terhadap pembuluh.

d. Jari-jari pada penampang (x) dan (t) tampak oleh mata sebagai jari-jari yang homogen, hanya memiliki satu ukuran saja.

e. Kayu memiliki tekstur sedang dan agak kasar.

f. Serat kayu memiliki arah serat yang lurus.

g. Saluran damar terdapat pada sampel kayu. Penyebaran saluran damar adalah tunggal. Berdasarkan deskripsi ciri-ciri struktur kayu

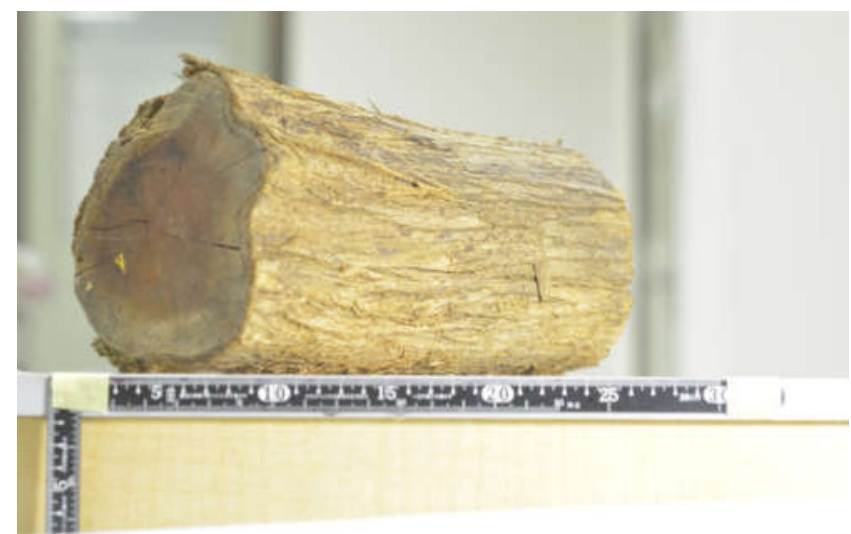

Gambar 1: Foto perspektif tiga dimensi obyek dengan sudut pandang dari bagian pangkal

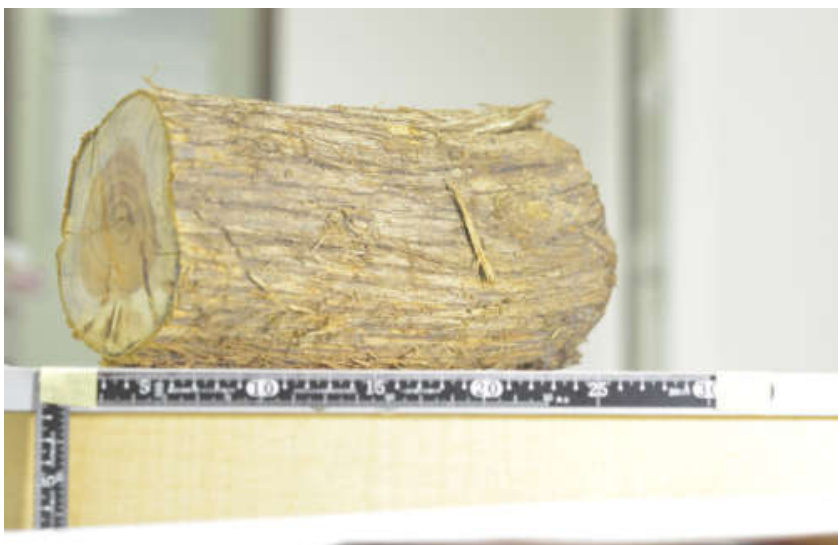

Gambar 2: Foto perspektif tiga dimensi obyek dari sudut pandang dari bagian ujung tersebut, maka dapat disimpulkan bahwa contoh-uji kayu ini merupakan jenis kayu Acacia leucophloea. Kesimpulan ini diperkuat oleh kesesuaian foto makroskopis penampang melintang contoh uji tersebut dengan foto makroskopis penampang melintang yang terdapat pada buku tulisan J. Ilic, halaman 33 pada gambar nomor 562. Gambar nomor 562 menampilkan nama Acacia leucophloea. Nama latin Acacia leucophloea Wild ini memiliki nama lokal pilang.

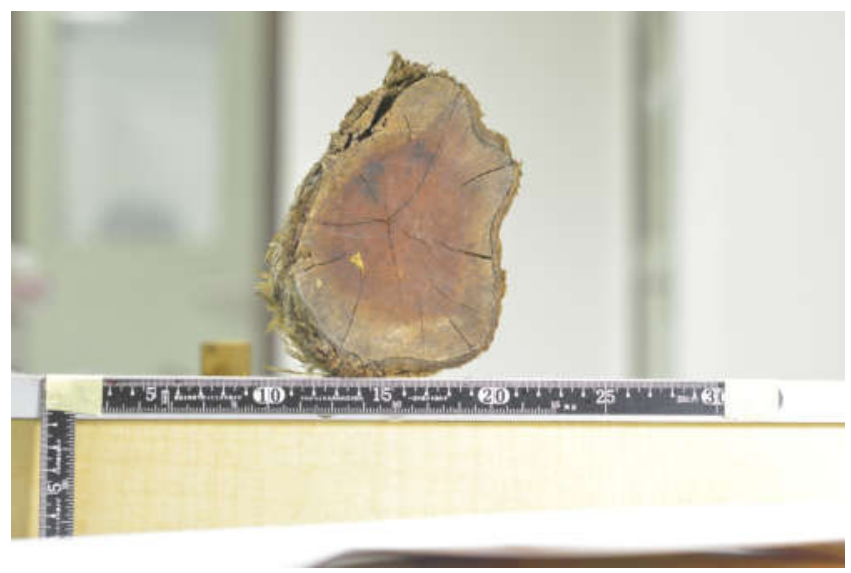

Gambar 3: Foto penampang melintang obyek dari sudut pandang bagian pangkal

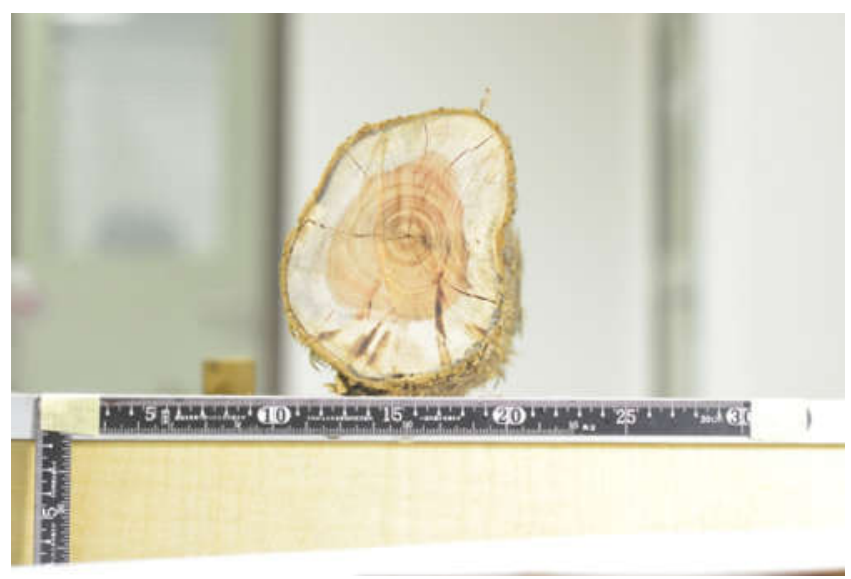

Gambar 4: Foto penampang melintang obyek dari sudut pandang bagian ujung

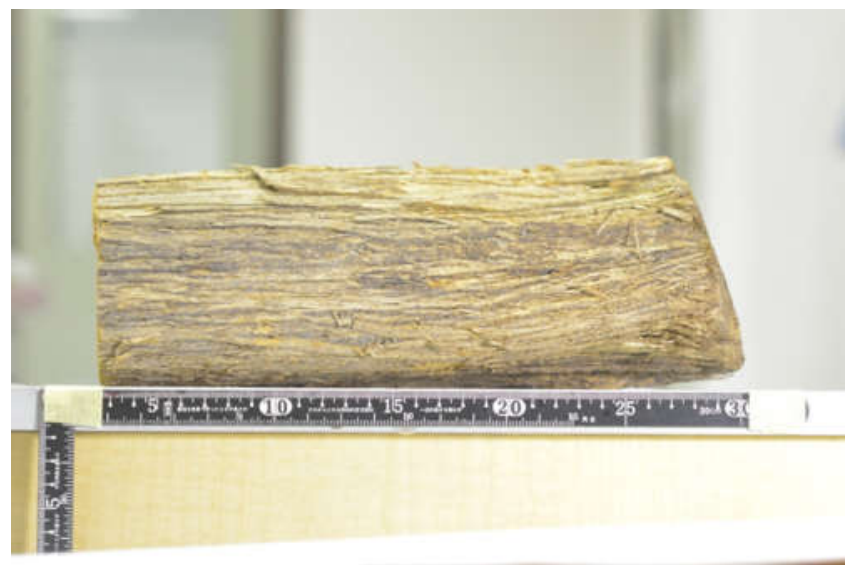

Gambar 5: Foto obyek dari sudut pandang bagian longitudinal batang 


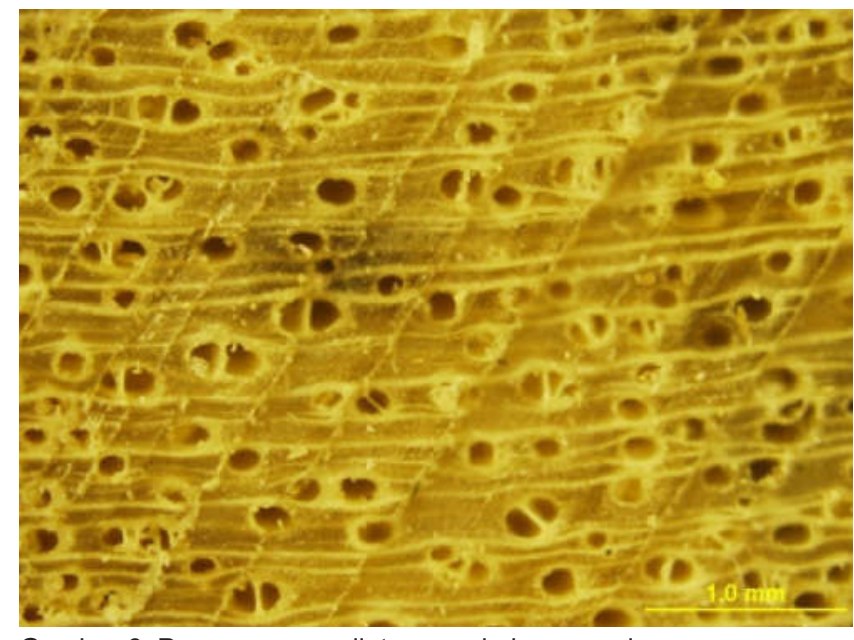

Gambar 6. Penampang melintang pada kayu awal

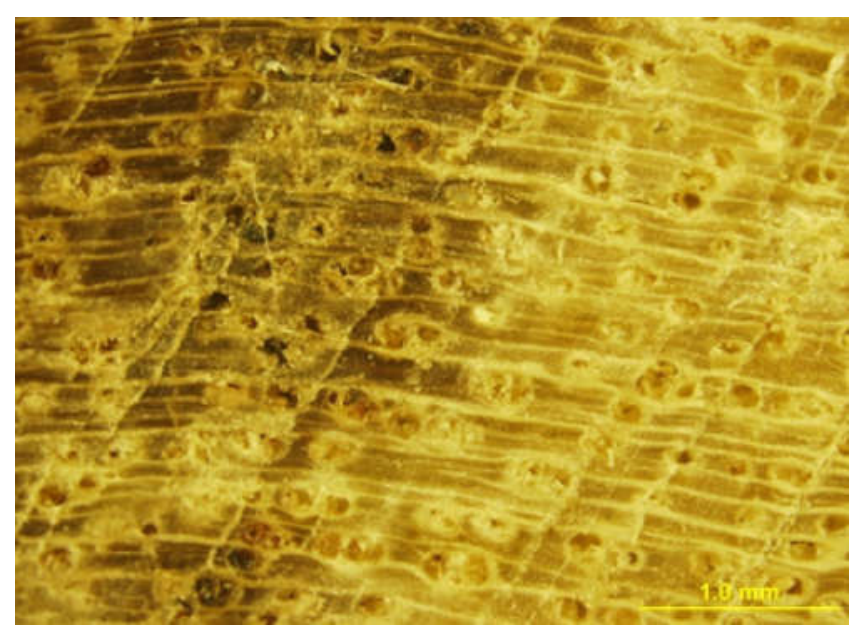

Gambar 7. Penampang melintang pada batas kayu akhir dan kayu awal

\subsection{Sifat Fisika Kayu}

Hasil pengukuran sifat fisika kayu dalam disajikan pada Tabel 1.

Berdasarkan Tabel 1, terlihat bahwa kayu ini memiliki kadar air 44,8\%, berat jenis 0,82 , penyusutan total arah radial $3,3 \%$ dan penyusutan total arah tangensial 4.2\%. Dari data itu, dapat dipahami bahwa kayu ini tergolong dalam kayu yang memiliki berat jenis yang tinggi. Di samping itu, kayu ini memiliki tingkat penyusutan yang relatif kecil, baik dalam penyusutan radial maupun penyusutan tangensial. Apabila dihitung ratio penyusutan tangensial dan radial, maka diperoleh angka $4,2 / 3,3=1,27$. Nilai ini mendekati angka 1 , sehingga kayu ini memiliki nilai stabilitas yang relatif tinggi. Tingkat kestabilan dimensi yang tinggi memungkinkan kayu ini digunakan sebagai kayu pasak perahu tradisional oleh masyarakat maritim Kabupaten Rembang.

\subsection{Sifat Mekanika Kayu}

Hasil pengukuran sifat mekanika kayu dalam kondisi kering udara disajikan pada Tabel 2 berikut.

Berdasarkan Tabel 2, terlihat bahwa kayu ini memiliki kekuatan geser 98,2 kg/ $\mathrm{cm}^{2}$, kekuatan belah 69,8 kg/cm dan kekuatan tekan sebesar $778 \mathrm{~kg} / \mathrm{cm}^{2}$. Berdasarkan data tersebut, kayu ini tergolong dalam kayu dengan kekuatan relatif tinggi. Tingginya kekuatan kayu dipengaruhi oleh berat jenis kayu yang tinggi pula. Penilaian ini didasari oleh teori yang menyatakan bahwa berat jenis merupakan parameter utama yang mementukan kekuatan kayu. Berdasarkan nilai kekuatan yang tinggi ini mungkin menjadi alasan mengapa komunitas masyarakat maritim setempat memanfaatkan kayu tersebut sebagai kayu pasak pada pembuatan perahu secara tradisional.

\subsection{Kualitas Kayu}

Penentuan kualitas kayu dilakukan berdasarkan parameter berat jenis dan kekuatan tekan. Secara berurutan, standar klasifikasi yang digunakan untuk menentukan kualitas kayu berurutan adalah Seng (1960) untuk parameter berat jenis dan Anonim (1976) untuk parameter kekuatan tekan. Hasilnya disajikan pada Tabel 3.

Berdasarkan Tabel 3 tersebut, terlihat bahwa kayu ini memiliki kelas kualitas 1 - 2. Berdasarkan kelas

Tabel 1. Hasil pengukuran sifat fisika kayu

\begin{tabular}{|c|c|c|c|c|}
\hline \multirow{2}{*}{$\begin{array}{c}\text { No } \\
\text { Contoh Uji }\end{array}$} & \multicolumn{4}{|c|}{ Parameter } \\
\cline { 2 - 5 } & Kadar air (\%) & Berat Jenis & Penyusutan total radial (\%) & Penyusutan total tangensial (\%) \\
\hline 1 & 48 & 0,80 & 3,5 & 4,6 \\
\hline 2 & 42 & 0,82 & 3,3 & 4,1 \\
\hline 3 & 46 & 0,84 & 3,2 & 4,3 \\
\hline 4 & 41 & 0,83 & 3,1 & 4,0 \\
\hline 5 & 47 & 0,81 & 3,4 & 4,5 \\
\hline Rata-rata & 44,8 & 0,82 & 3,3 & 4,2 \\
\hline
\end{tabular}


Tabel 2. Hasil pengukuran sifat mekanika kayu

\begin{tabular}{|c|c|c|c|}
\hline \multirow{2}{*}{$\begin{array}{c}\text { No } \\
\text { Contoh Uji }\end{array}$} & $\begin{array}{c}|c| \\
\text { Kekuatan } \\
\text { geser } \\
\left(\mathbf{k g} / \mathrm{cm}^{2}\right)\end{array}$ & $\begin{array}{c}\text { Kekuatan } \\
\text { Belah } \\
(\mathbf{k g} / \mathrm{cm})\end{array}$ & $\begin{array}{c}\text { Kekuatan } \\
\text { Tekan } \\
\left(\mathbf{k g} / \mathrm{cm}^{2}\right)\end{array}$ \\
\hline 1 & 96,3 & 66,8 & 786 \\
\hline 2 & 101,1 & 72,0 & 776 \\
\hline 3 & 100,0 & 73,6 & 780 \\
\hline 4 & 95,2 & 72,8 & 775 \\
\hline 5 & 102,2 & 67,8 & 781 \\
\hline 6 & 94,4 & 65,9 & 778 \\
\hline 7 & - & 69,7 & 770 \\
\hline Rata-rata & 98,2 & 69,8 & 778 \\
\hline
\end{tabular}

Tabel 3. Hasil penentuan kualitas kayu

\begin{tabular}{|c|c|c|c|}
\hline No & Parameter & $\begin{array}{c}\text { Nilai } \\
\text { rata rata }\end{array}$ & $\begin{array}{c}\text { Kelas kualitas } \\
\text { kayu }\end{array}$ \\
\hline 1 & Berat Jenis & 0,82 & 2 \\
\hline 2 & $\begin{array}{c}\text { Kekuatan Tekan } \\
\left(\mathrm{kg} / \mathrm{cm}^{2}\right)\end{array}$ & 778 & 1 \\
\hline & Rata-rata & & $1-2$ \\
\hline
\end{tabular}

kualitas yang dimilikinya, maka kayu ini merupakan kualitas unggul. Hal ini disebabkan peringkat kualitas kayu dibedakan menjadi lima kelas, yaitu kelas satu sampai dengan kelas lima. Semakin tinggi peringkat kelas kayu, maka semakin unggul kualitas kayu tersebut.Berdasarkan nilai kualitas kayu yang berkisar pada status sangat baik sampai dengan status baik ini mungkin menjadi alasan mengapa komunitas masyarakat maritim setempat memanfaatkannya sebagai kayu pasak pada pembuatan perahu secara tradisional.

\section{Penutup}

\subsection{Kesimpulan}

Hasil penelitian karakterisasi kayu pasak baru menyimpulkan lima hal, yaitu:

1. Obyek penelitian memiliki dimensi diameter bagian pangkal 14,5 cm, diameter bagian ujung $12,5 \mathrm{~cm}$ dan panjang $28 \mathrm{~cm}$.

2. Jenis kayu adalah Acacia leucophloeaWild, atau dalam bahasa perdagangan bernama kayu pilang.

3. Sifat fisika kayu meliputi kadar air 44,8\%, berat jenis 0,82 , penyusutan total radial 3,3\% dan penyusutan total tangensial $4,2 \%$ serta nilai stabilitas dimensi adalah 1,27.

4. Sifat mekanika kayu meliputi kekuatan geser $98,2 \mathrm{~kg} / \mathrm{cm}^{2}$, kekuatan belah $69,8 \mathrm{~kg} / \mathrm{cm}^{2}$, dan kekuatan tekan sejajar serat $778 \mathrm{~kg} / \mathrm{cm}^{2}$.

5. Kelas kualitas kayu adalah $1-2$ dengan predikat sebagai kayu yang sangat baik atau kayu baik.

\subsection{Saran}

Disarankan agar penentuan jenis dan karakter kayu baru yang digunakan sebagai pengganti kayu lama wajib dilakukan sebelum melaksanakan proses rekonstruksi dan pemugaran Benda Cagar Budaya. Hal ini dimaksudkan agar prinsip orisinalitas bahan sebagaimana diamanatkan dalam Undang-Undang Republik Indonesia Nomor 11 tahun 2010 tentang Cagar Budaya dapat diwujudkan, sehingga keaslian Benda Cagar Budaya dapat dipertahankan. Penulis menyampaikan ungkapan terima kasih kepada Fakultas Kehutanan Universitas Gadjah Mada Yogyakarta yang telah membeayai pelaksanaan penelitian ini dalam skema Penelitian LKD tahun 2015. 


\section{DAFTAR PUSTAKA}

Anonim, 1976. Vademecum Kehutanan Indonesia. Direktorat Jenderal Kehutanan. Departeman Pertanian.

Anonim (tanpa tahun). Museum. Wikipedia. Sumber: http://en.wikipedia.org/wiki/Museum diunduh pada 19 Oktober 2013.

Forest Products Laboratory, 1999. Wood HandbookWood as an Engineering Material. Gen. Tech. Rep. FPL-GTR-113. Madison, WI: U.S. Department of Agriculture, Forest Service, Forest Products Laboratory. 463 p.

Kollmann F.E.P., dan Cote, W.A., 1968. Principle of Wood Science and Technology. Volume I. Springer-Verlag. New York Inc.

Prawirohatmodjo, S. 2001. Sifat-sifat Mekanika Kayu. Bagian Penerbitan. Fakultas Kehutanan Universitas Gadjah Mada. Yogyakarta.
Presiden Republik Indonesia, 2010. Undang-Undang Republik Indonesia Nomor 11 tahun 2010 tentang Cagar Budaya. Lembaran Negara Republik Indonesia.

Shmulsky, R dan Jones, D., 2011. Forest Product and Wood Science. An Introduction. 6 edition. Wiley-Blackwell Publication. United Kingdom.

Soenardi, P., 1976. Sifat Fisike Kayu. Yayasan Pembina Fakultas Kehutanan Universitas Gadjah Mada. Yogyakarta.

-------------, 1977. Ilmu Kayu. Yayasan Pembina Fakultas Kehutanan, Universitas Gadjah Mada. Yogyakarta. Widianto, H., 2015. Kebijakan Pelestarian Cagar Budaya, Khususnya Konservasi Cagar Budaya Bawah Air. Makalah. Direktur Direktorat Pelestarian Cagar Budaya dan Permuseuman disampaikan pada Workshop Konservasi Watterlogged Wood. Rembang. 